\title{
Water quality in the Mondego river basin: pollution and habitat heterogeneity
}

\author{
Verónica Ferreira*, Manuel A.S. Graça, Maria João Feio \& Claúdia Mieiro \\ IMAR - Centro Interdisciplinar de Coimbra, Departamento de Zoologia, Universidade de Coimbra, 3004- \\ 517 Coimbra, Portugal \\ * Author for correspondence: veronica@ci.uc.pt
}

\begin{abstract}
The "IMAR- Departamento de Zoologia, Universidade de Coimbra" and "Direcção Regional de Ambiente e Ordenamento do Território" started a partnership with the objective of establishing bases for the assessment of water quality in the Mondego river basin. Here we present the preliminary results of the study. We sampled 75 sites covering the Mondego river basin. At each site we took 18 physical and chemical measurements and sampled macroinvertebrates with a hand net. Site quality was assessed by the application of a biotic index (BMWP'), water chemistry and habitat heterogeneity. Fifty two percent of the sites had good biological water quality (based on BMWP' index). The strongly polluted sites were concentrated in the Lower Mondego region. Thirty three percent of sites had bad chemical water quality and $45 \%$ of the sites had low habitat complexity. Only $40 \%$ of the sites with low biological quality also had low chemical water quality. We concluded that (1) in general, the waters on the Mondego river basin do not suffer from strong water pollution and (2) low BMWP' values can be explained by low water quality or low habitat heterogeneity (natural or man-made).
\end{abstract}

Key words: biological water quality, chemical water quality, habitat heterogeneity, BMWP'.

\section{RESUMEN}

El "IMAR-Departamento de Zoologia, Universidade de Coimbra" y la "Direcção Regional de Ambiente e Ordenamento do Território" iniciaron una colaboración con el objetivo de establecer las bases para la evaluación de la calidad del agua en la cuenca hidrográfica del Río Mondego. En esta publicación presentamos los datos preliminares de ese estudio. Se muestrearon 75 localidades, repartidas por toda la cuenca del Mondego. En cada localidad se midieron 18 parámetros químicos y físicos y se muestreó la comunidad de macroinvertebrados acuáticos con una red de mano. La calidad ambiental fue calculada mediante la aplicación del índice biótico BMWP', por las características químicas del agua y por la heterogeneidad del hábitat. Un $51 \%$ de las localidades muestreadas tenían una buena calidad ambiental, de acuerdo con el indice BMWP'. Los sitios fuertemente contaminados estaban concentrados en la zona del Bajo Mondego. Un 33\% de los locales tenían una calidad química mala, mientras que el 45\% tenían una baja heterogeneidad del hábitat. Solamente un 40\% de las localidades con baja calidad biológica también tenían baja calidad química. Concluimos que (1) en general, las aguas de la cuenca del río Mondego no sufre de contaminaciones fuertes, y (2) que los bajos valores de BMWP'pueden ser explicados por la baja calidad del agua o bien por una baja heterogeneidad del hábitat (por causas humanas o naturales).

Palabras clave: calidad biológica del agua, calidad química del agua, heterogeneidad del hábitat, BMWP'.

\section{INTRODUCTION}

The increase in water necessities for domestic, industrial and agricultural use has led to an increase in water consumption and contributed to the degradation of the water quality. Since water degradation results mainly from chemical changes in water, early standard methods for assessing quality relayed on water chemistry. According to Metcalfe (1989), biological assessments offer important advantages over chemical assessments: (1) they are more sensitive than chemical methods under conditions of toxic, intermittent or organic pollution; (2) they detect the more subtle disruptions as well as non-source pollution; (3) they measure actual effects on 
biota, whereas chemical methods must be interpreted on a biological basis; and (4) organisms integrate environmental conditions over long periods of time, whereas chemical data are instantaneous and therefore require large numbers of measurements for an accurate assessment.

Biotic indices are numeric expressions that classify water quality based on the ecological sensitivity of the taxa present and on the taxa richness. Many biotic indices are based on macroinvertebrates because they occupy a central role in the aquatic ecosystem by participating in the decomposition of organic matter and by constituting the major food source for other aquatic invertebrates, fishes and some birds (Callisto et al., 2001).

An example of a biotic index based on macroinvertebrates is the BMWP index, originally developed in Great Britain (Armitage et $a l .$, 1983) and then adapted to the Iberian Peninsula (Alba-Tercedor \& Sánchez-Ortega, 1988; Alba-Tercedor, 1996). This index requires only qualitative data and macroinvertebrates are identified only to family level. Although the index is expected to respond negatively with an increase in organic pollution, low values may also reflect low habitat heterogeneity (Armitage et al., 1983; Blijswijk et al., 2005; Oliveira et al., 2001). The goals of this study were (1) to elaborate a map of biological quality of the Mondego river basin, the largest single basin located entirely in Portugal, and (2) to estimate the effect of pollution and habitat heterogeneity on the BMWP' scores values.

\section{METHODS}

\section{Study area}

The source of the Mondego River is located in the "Serra da Estrela" mountain (Central Portugal), at $1547 \mathrm{~m}$ above sea level. The river flows along $227 \mathrm{Km}$ into the Atlantic Ocean, draining a hydrological basin of about 6670 $\mathrm{Km}^{2}$, the largest single basin located entirely in Portuguese territory (Marques et al., 2002). It is possible to divide the Mondego basin into 3 areas, according with hydro-morphologic characteristics; the Upper Mondego region, which comprises the mountainous region drained by the upper Dão and Alva tributaries and the upper part of the Mondego river, is mainly composed of granite; the Middle Mondego region, which comprises the area between the base of Serra da Estrela Mountain and the city of Coimbra, is mainly schistose. This section contains the final parts of the Dão, Alva and Ceira tributaries; and the Lower Mondego region that spans from the city of Coimbra to the sea (Figueira da Foz), and where the main tributaries are Pranto, Arunca and Ega, is calcareous (Marques et al., 2002). In this basin, land is mostly used for coniferous forest plantations $(22 \%)$, mix forest plantations (21\%), agriculture $(25 \%)$ and furze-field and pasture (15\%) (INAG, 2003). The Lower Mondego region is comprised of 15,000 hectares of good agricultural land where the main crops are rice $(60 \%$ of the valley), corn, and beans (18\% of the valley), which require the use of great amounts of fertilizers and pesticides. Another important economic activity is wood extraction for pulp production for which there are large extensions of Eucalyptus globulus plantations in the central part of the basin (Marques et al., 2002; DGF, 2003). The main sources of pollution in this basin are collective sepias ditches (75\%), wastewater treatment plants $(18 \%)$, and direct discharges of urban sewage (7\%) (INAG, 2003). We sampled a total of 75 sites distributed all over the basin and covering altitudinal, geological, and stream size gradients. The lowland main channel of the river was avoided due to sampling methodology restrictions and because its artificial configuration.

\section{Sampling, sorting, and identification of macroinvertebrates}

Samples were taken between June and September, 2001, by kick sampling with a hand net $(0.3 \times 0.3 \mathrm{~m}$ opening and $0.5 \mathrm{~mm}$ mesh size) covering a transept of approximately 6 meters in 
3 minutes. The transept was perpendicular to the riverbanks and was set to cover all major microhabitats. In addition, invertebrates were obtained from 10 different stones randomly retrieved from the streambed at each site. The stones were inspected in situ and invertebrates removed and placed in plastic bags. This is a modification of the methodology described by Alba-Tercedor \& Sánchez-Ortega (1988). The hand- net and "stone" samples were stored individually. Samples were conserved in $4 \%$ formalin until they were sorted. In the lab, each sample was washed through a sieve series $(0.5-1.0-2.0 \mathrm{~mm})$ to increase sorting efficiency. The macroinvertebrates were sorted and stored in $70 \%$ ethanol for further identification. Identification was made to family level except for mites (Hydracarina), Oligochaeta, and Hydridae.

\section{Particulate organic matter}

After removing the invertebrates, we determined the particulate organic matter of each sample (total area of approximately $6 \times 0.3 \mathrm{~m}$ ) and fraction: fine fraction (FPOM: $0.5-1 \mathrm{~mm}$ ) and coarse fraction (CPOM: $>1 \mathrm{~mm}$ ). Each fraction was dried in a stove at $70^{\circ} \mathrm{C}$ for $24 \mathrm{~h}$, weighed, placed in a muffle at $550^{\circ} \mathrm{C}$ for $4 \mathrm{~h}$ and reweighed, to obtain ash free dry mass (AFDM).

\section{Environmental parameters and habitat characterization}

Variables measured at sampling sites included river width, mean depth ( $\mathrm{n}=3$ or $6 /$ site), mean current velocity ( $\mathrm{n}=3$ or $6 /$ site; VALEPORT 15277), dissolved oxygen ( $\%$ and $\mathrm{mg} / \mathrm{L}$; WTW OXI 92), pH (JENWAY 3310), conductivity and total dissolved solids (WTW LF 330), temperature, and mean substrate size ( 9 or 18 substrate particles from the substratum/site).

Habitat assessment was made based on habitat complexity - heterogeneity: a site with a variety of types (logs, branches, boulders and aquatic vegetation) and sizes of material was considered an optimal site; a site where structural types or sizes of material were less than optimum but where adequate cover was still provided was considered a sub optimal site; a site dominated by only one or two structural components was considered a marginal site; and a site with homogeneous, simple habitats (where silt and sand dominate) was considered a poor site. Pool quality was also assessed into 4 classes: optimal (river bed with all 4 possible combinations of depth (shallow / deep) and current velocity (low / high)), sub-optimal (river bed with 3 of the 4 possible combinations), marginal (two combinations) and poor (homogeneous pool) (EPA, 1999).

\section{Water chemistry}

At each site $600 \mathrm{~mL}$ of water were collected into acid washed plastic bottles. Water samples were transported to the laboratory in an ice chest. Water was analyzed for ammonia, nitrate, nitrite, sulfate, phosphate and chloride, using an ion analyzer (Dionex DX-120). We also measured alkalinity by titration to an end $\mathrm{pH}$ of 4.5 (A.P.H.A., 1995).

The chemical water quality index was determined based on concentrations of the 6 ions. We considered a site to have bad chemical water quality if at least one ion was in excess, according with the Decree-law no 236/98 of August $1^{\text {st }}$ (Rocha \& Vieira, 1998), which gives the threshold values for the different ions in water for human consumption.

\section{BMWP' index}

For the application of the BMWP' index, we considered a family as present, when more than one individual was counted. The family Calamoceratidae (Trichoptera) is not considered in the original or adapted version of the index. However, in this study we found the Calamoceratidae family in 9 sites $(>1$ individual), 3 of which with very high abundances. In consequence we included this family in the table and gave it a score of 6 . This score is arbitrary and was achieved by looking at the most polluted site where the Calamoceratidae family appeared (Louriçal) and giving it the same 
Table 1. Presence of macroinvertebrate "families" in the Mondego River basin. Presencia de "familias" de macroinvertebrados en la cuenca del río Mondego.

\begin{tabular}{|c|c|c|c|c|c|}
\hline Taxa & $\mathrm{N}^{\circ}$ of sites & Taxa & $\mathbf{N}^{0}$ of sites & Taxa & $N^{0}$ of sites \\
\hline Hydridae & 2 & Heptageniidae & 42 & Ecnomidae & 13 \\
\hline Dugesiidae & 26 & Leptophlebiidae & 55 & Glossosomatidae & 19 \\
\hline Planariidae & 16 & Oligoneuridae & 3 & Goeridae & 15 \\
\hline Nemathelmintha & 12 & Leuctridae & 60 & Helichopsychidae & 1 \\
\hline Ancylidae & 47 & Nemouridae & 16 & Hydropsychidae & 55 \\
\hline Hydrobiidae & 38 & Perlidae & 7 & Hydroptilidae & 13 \\
\hline Lymnaeidae & 5 & Aeshnidae & 22 & Lepidostomatidae & 23 \\
\hline Physidae & 16 & Calopterygidae & 17 & Leptoceridae & 41 \\
\hline Planorbidae & 8 & Cordulegasteridae & 24 & Limnephilidae & 22 \\
\hline Valvatidae & 2 & Gomphidae & 41 & Philopotamidae & 19 \\
\hline Corbiculidae & 2 & Lestidae & 2 & Phryganeidae & 13 \\
\hline Sphaeriidae & 11 & Platycnemidae & 11 & Polycentropodidae & 44 \\
\hline Unionidae & 1 & Aphelocheiridae & 3 & Psychomyiidae & 39 \\
\hline Echytraeidae & 11 & Corixidae & 20 & Rhyacophilidae & 35 \\
\hline Haplotaxidae & 5 & Gerridae & 27 & Sericostomatidae & 35 \\
\hline Lumbricidae & 31 & Hydrometridae & 9 & Uenoidae & 3 \\
\hline Lumbriculidae & 56 & Nepidae & 6 & Athericidae & 38 \\
\hline Naididae & 39 & Notonectidae & 6 & Anthomyiidae & 7 \\
\hline Tubificidae & 26 & Vellidae & 3 & Blephariceridae & 2 \\
\hline Erpobdellidae & 30 & Dryopidae & 15 & Ceratopogonidae & 22 \\
\hline Glossophoniidae & 12 & Dytiscidae & 6 & Chironomidae & 75 \\
\hline Acari & 63 & Elmidae & 64 & Dixidae & 8 \\
\hline Ostracoda & 5 & Gyrinidae & 8 & Dolichopodidae & 1 \\
\hline Copepoda & 6 & Haliplidae & 8 & Ephydridae & 4 \\
\hline Asellidae & 5 & Hydraenidae & 23 & Empididae & 29 \\
\hline Cambaridae & 6 & Hydrochidae & 11 & Limoniidae & 17 \\
\hline Atyidae & 11 & Hydrophilidae & 27 & Psychodidae & 10 \\
\hline Gammaridae & 1 & Hydroscaphidae & 2 & Rhagionidae & 5 \\
\hline Colembolla & 1 & Scirtidae & 3 & Sciomyzidae & 1 \\
\hline Baetidae & 71 & Sialidae & 16 & Simuliidae & 50 \\
\hline Caenidae & 51 & Beraidae & 4 & Tabanidae & 10 \\
\hline Ephemerellidae & 39 & Brachycentridae & 2 & Tipulidae & 12 \\
\hline Ephemeridae & 10 & Calamoceratidae & 14 & & \\
\hline
\end{tabular}

value as the most intolerant family present (Ancylidae), knowing that this can be over scoring this family. Based on BMWP' score we used the 5 biological water quality classes: I (BMWP'> 100), pollution free waters or high quality; II (BMWP': 61-100), good quality; III (BMWP': 36-60), moderate quality; IV (BMWP': 16-35), poor quality and V (BMWP'<15), strongly polluted or bad quality. The ASPT' value for each site was computed by dividing the BMWP' value of each site by the total number of BMWP' families present at the considered site (Alba-Tercedor, 1996).

\section{RESULTS}

Ninety-eight "families" of macroinvertebrates were identified. Fifty six percent of the total individuals were members of the families Chironomidae, Hydrobiidae and Baetidae. Forty-one families were very rare, together contributing with less than 1000 individuals $(<1 \%)$ for a total of 137,000. Ten families were present at almost all sites, whereas 20 families were rare, having appeared in less than 5 sites (Table 1). The sites with higher number of individuals (> 4000) were Tentúgal (17711), Anobra (6807), 
Vimieiro (5240), Porto da Carne (5161), Miranda do Corvo (5084), Ribamondego (4777), Carqueijal (4711), S. Miguel de Vila Boa (4612), and Louriçal (4454). The sites with lower number of individuals $(<200)$ were Liceia (35), Vila Moinhos (48), Nascente do Catarredor (83), Campizes (97), Casal Ermio (101), Vila Nova do Ceira (120), and Tondela (158) (see table 2). Six sites presented more than 50 different taxa: Ribamondego (61), S. Miguel de Vila Boa (59), Nespereira (59), Casal Mundão (58), Carqueijal (57), and Sabugueiro
(53), and 10 sites presented less than 20 different taxa: Soure (8), Vila Moinhos (10), Liceia (13), Campizes (14), Nascente do Catarredor (15), S. Paio do Mondego (16), Casal Ermio (18), Foz do Alva (19), Tondela (19), and Casal da Rola (19). The sites with the lower number of individuals were also the ones presenting lower number of taxa, however the opposite didn't happen for sites with higher number of individuals. This may be explained by the fact that in some sites there's a high number of individuals, but most of them belonging to the same family.

Table 2. Stream name, total number of individuals, number of BMWP' taxa, number of intolerant taxa (sum of BMWP' taxa with a score of 7 , 8 and 10), BMWP' value and ASPT' value for the 75 sites sampled in the Mondego river basin, in summer 2001. Nombre del río, número total de individuos, número de familias para BMWP', número de taxa intolerantes (suma de taxa con valores de 7, 8 y 10 para BMWP'), valores de $B M W P$ 'y ASPT'para las 75 localidades muestreadas en la cuenca del río, en verano de 2001.

\begin{tabular}{|c|c|c|c|c|c|c|c|}
\hline Number & Site & Stream name & $\begin{array}{c}\text { No. } \\
\text { individuals }\end{array}$ & $\begin{array}{l}\text { No. BMWP' } \\
\operatorname{taxa}\end{array}$ & $\begin{array}{c}\text { No.Intolerant } \\
\text { taxa }\end{array}$ & BMWP' & ASPT \\
\hline 1 & Botão & Ribeira do Botão & 1393 & 15 & 7 & 92 & 6.13 \\
\hline 2 & Lorvão & Ribeira do Lorvão & 2929 & 20 & 2 & 87 & 4.35 \\
\hline 3 & Rebordosa & Ribeira do Lorvão & 1293 & 26 & 8 & 150 & 5.77 \\
\hline 4 & Tábuas & Ribeira da Nossa Sra. da Piedade & 931 & 14 & 7 & 100 & 7.14 \\
\hline 5 & Ponte do Espinhal & Rio Dueça & 551 & 19 & 8 & 119 & 6.26 \\
\hline 6 & Miranda do Corvo & Rio Dueça & 5084 & 13 & 3 & 67 & 5.15 \\
\hline 7 & Tourigo & Ribeira de Marruge & 423 & 19 & 10 & 128 & 6.74 \\
\hline 8 & Vila Moinhos & Ribeira da Fraga & 48 & 5 & 1 & 20 & 4.00 \\
\hline 9 & Vila Gozendo & Ribeira da Fraga & 493 & 18 & 5 & 99 & 5.50 \\
\hline 10 & Póvoa & Ribeira de Mortágua & 493 & 13 & 4 & 69 & 5.31 \\
\hline 11 & Vendas de Ceira 1 & Rio Ceira & 730 & 16 & 6 & 87 & 5.44 \\
\hline 12 & Vendas de Ceira 2 & Rio Dueça & 385 & 12 & 4 & 65 & 5.42 \\
\hline 13 & Foz de Arouce & Rio Ceira & 879 & 20 & 7 & 113 & 5.65 \\
\hline 14 & Casal de Ermio & Rio Ceira & 101 & 7 & 2 & 45 & 6.43 \\
\hline 15 & Múceres & Rio de Múceres & 981 & 25 & 14 & 168 & 6.72 \\
\hline 16 & Carqueijal & Ribeira do Farreco & 4711 & 32 & 12 & 172 & 5.38 \\
\hline 17 & Vila Nova de Ceira & Rio Ceira & 120 & 9 & 3 & 36 & 4.00 \\
\hline 18 & Góis & Rio Ceira & 407 & 15 & 4 & 81 & 5.40 \\
\hline 19 & Cabreira & Rio Ceira & 780 & 25 & 10 & 148 & 5.92 \\
\hline 20 & Candosa & Ribeira do Carvalhal Sapo & 1186 & 23 & 8 & 129 & 5.61 \\
\hline 21 & Lousã & Ribeira de S.João & 1604 & 21 & 10 & 140 & 6.67 \\
\hline 22 & Candal & Ribeira do Candal & 865 & 16 & 7 & 102 & 6.38 \\
\hline 23 & Nascente do Catarredor & Ribeira do Catarredor & 83 & 6 & 3 & 36 & 6.00 \\
\hline 24 & Golpilhares & Ribeira Barroca da Tijosa & 353 & 16 & 9 & 109 & 6.81 \\
\hline 25 & Santa Eulália & Ribeira do Esporão & 3018 & 17 & 2 & 72 & 4.24 \\
\hline 26 & Arrifana & Ribeira do Vodra & 1668 & 13 & 5 & 69 & 5.00 \\
\hline 27 & S.João da Boa Vista & Ribeira da Tábua & 841 & 27 & 13 & 166 & 6.15 \\
\hline 28 & Ançã & Ribeira de Ançã & 1468 & 16 & 3 & 69 & 4.31 \\
\hline 29 & Tentúgal & Ribeira de Moinhos & 17711 & 21 & 6 & 105 & 5.00 \\
\hline 30 & Liceia & Rio do Fojo & 33 & 7 & 1 & 25 & 3.57 \\
\hline 31 & Ferreira-a-Nova & Ribeira das Barreiras & 460 & 12 & 2 & 53 & 4.42 \\
\hline 32 & Fornos de Algodres & Rio Mondego & 646 & 13 & 6 & 80 & 6.15 \\
\hline
\end{tabular}


Table 2. (Continuation.)

\begin{tabular}{|c|c|c|c|c|c|c|c|}
\hline 33 & Vila Franca de Serra & Ribeira de Linhares & 786 & 20 & 8 & 119 & 5.95 \\
\hline 34 & Ribamondego & Ribeira do Freixo & 4777 & 34 & 16 & 206 & 6.06 \\
\hline 35 & Vila Cortêz da Serra & Ribeira do Paço & 1056 & 26 & 10 & 153 & 5.88 \\
\hline 36 & Nespereira & Ribeira de Gouveia & 3748 & 27 & 6 & 126 & 4.67 \\
\hline 37 & Sandomil & Rio Alva & 741 & 19 & 8 & 114 & 6.00 \\
\hline 38 & Caldas de S.Paulo & Rio Alva & 1172 & 22 & 14 & 155 & 7.05 \\
\hline 39 & Alvoco das Várzeas & Ribeira do Alvoco & 409 & 16 & 7 & 100 & 6.25 \\
\hline 40 & Avô 1 & Rio Alva & 2263 & 20 & 8 & 113 & 5.65 \\
\hline 41 & Avô 2 & Ribeira da Moura & 1189 & 20 & 9 & 117 & 5.85 \\
\hline 42 & Foz do Alva & Rio Alva & 412 & 10 & 3 & 50 & 5.00 \\
\hline 43 & Vimeiro & Rio Alva & 5240 & 16 & 7 & 92 & 5.75 \\
\hline 44 & S. Paio do Mondego & Ribeira de S.Paulo & 825 & 8 & 2 & 40 & 5.00 \\
\hline 45 & Folques & Ribeira de Folques & 2615 & 29 & 13 & 177 & 6.10 \\
\hline 46 & Côja 1 & Rio Alva & 3743 & 18 & 9 & 114 & 6.33 \\
\hline 47 & Côja 2 & Ribeira da Mata & 2421 & 26 & 9 & 150 & 5.77 \\
\hline 48 & Vinhó & Ribeira do Casal & 2186 & 23 & 13 & 156 & 6.78 \\
\hline 49 & Porto da Balsa & Ribeira da Castanheira & 2026 & 21 & 10 & 134 & 6.38 \\
\hline 50 & Pombal & Rio Arunca & 1446 & 20 & 6 & 110 & 5.50 \\
\hline 51 & Ponte de Assamaça & Ribeira de Valmar & 1285 & 16 & 3 & 65 & 4.06 \\
\hline 52 & Louriçal & Ribeira das Castelhanas & 4454 & 12 & 0 & 45 & 3.75 \\
\hline 53 & Casal da Rola & Ribeira de Carnide & 462 & 10 & 1 & 41 & 4.10 \\
\hline 54 & Soure & Rio de Anços & 705 & 3 & 0 & 10 & 3.33 \\
\hline 55 & Vale dos Azares & Ribeira da Cabeça Alta & 2602 & 26 & 11 & 159 & 6.12 \\
\hline 56 & Trinta & Rio Mondego & 1289 & 19 & 12 & 131 & 6.89 \\
\hline 57 & Porto da Carne & Rio Mondego & 5161 & 20 & 6 & 102 & 5.10 \\
\hline 58 & Minhocal & Ribeira dos Tamanhos & 2199 & 21 & 8 & 119 & 5.67 \\
\hline 59 & Cardal & Ribeira Quinta das Seixas & 808 & 26 & 11 & 157 & 6.04 \\
\hline 60 & Muxagata & Ribeira de Muxagata & 1134 & 15 & 2 & 71 & 4.73 \\
\hline 61 & Póvoa da Rainha & Rio Mondego & 374 & 16 & 7 & 99 & 6.19 \\
\hline 62 & Sabugueiro & Ribeira de Fervença & 3954 & 27 & 12 & 162 & 6.00 \\
\hline 63 & Campizes & Ribeiro do Gaio & 97 & 4 & 0 & 9 & 2.25 \\
\hline 64 & Anobra & Ribeira de Arzila & 6807 & 15 & 3 & 77 & 5.13 \\
\hline 65 & Vila da Barba & Ribeiro do Poto & 472 & 24 & 11 & 146 & 6.08 \\
\hline 66 & Várzea & Ribeira da Mata & 1277 & 11 & 4 & 61 & 5.55 \\
\hline 67 & Travanca de S.Tomé & Ribeira de Cabanas & 809 & 20 & 9 & 120 & 6.00 \\
\hline 68 & Tondela & Rio Dinha & 158 & 8 & 2 & 43 & 5.38 \\
\hline 69 & Casal de Mundão & Ribeira da Fraga & 1686 & 31 & 10 & 171 & 5.52 \\
\hline 70 & Alcafache & Rio Dão & 572 & 16 & 6 & 90 & 5.63 \\
\hline 71 & Fail & Rio Paiva & 3999 & 11 & 1 & 46 & 4.18 \\
\hline 72 & Antas & Ribeira do Carrapito & 2255 & 19 & 8 & 115 & 6.05 \\
\hline 73 & Penalva do Castelo & Rio Dão & 332 & 16 & 9 & 105 & 6.56 \\
\hline 74 & S.Miguel da Vila Boa & Ribeira de Satão & 4612 & 31 & 14 & 183 & 5.90 \\
\hline 75 & Senhorim & Rio do Saldo & 412 & 14 & 2 & 61 & 4.36 \\
\hline
\end{tabular}

The BMWP' index classified 14 sites (19\%) as being moderately to highly polluted (classes IIIV), 22 sites (29\%) as being of good quality (class II) and 39 sites (52\%) as lightly or not polluted (class I) (Table 2 and Fig. 1). The BMWP' values are explained by both the type and number of taxa present in each site; so, a site with a high number of intolerant taxa (score: 7-10) will present a high BMWP' value (for example, Caldas de S. Paulo with $64 \%$ of intolerant taxa has an index value of 155); on the other hand, a site with a low number of intolerant taxa will present a low BMWP' value (for example, Soure and Campizes with $0 \%$ of intolerant taxa have an index value of 10 and 9 , respectively). However, a site with a low number of 
intolerant taxa, but with a high total number of taxa may present a high BMWP' value (for example, Nespereira with only $22 \%$ of intolerant taxa, but with 27 BMWP' taxa, has an index value of 126); on the other hand, a site with a high percentage of intolerant taxa, but with a low total number of taxa can present a low BMWP' value (for example, Nascente do Catarredor with $50 \%$ of intolerant taxa, but with only 6 BMWP' taxa, has an index value of 36). However, it seems like the BMWP' values are more related to the total number of BMWP' taxa considered in the index calculation $\left(\mathrm{R}^{2}=\right.$ 0.9255 ) than to the type of taxa (number of intolerant taxa, $\mathrm{R}^{2}=0.8982$ ). There was no relationship between the BMWP' values and the ASPT' values $\left(\mathrm{R}^{2}=0.4565\right)$. Also, there was no relationship between the number of individuals and the BMWP' values $\left(\mathrm{R}^{2}=0.0371\right)$. This could be explained by the fact that in some sites there was a large number of individuals $(>4000)$ but most of them belonging to the same family; for example, in Tentúgal, Anobra and Louriçal, 98,84 and $58 \%$ of the individuals belong to the
Hydrobiidae family; in Vimieiro, $81 \%$ of the individuals belong to the families Leuctridae, Hydropsychidae, Philopotamidae, Chironomidae; in Miranda do Corvo and Fail, 81 and $51 \%$ of the individuals belong to the Chironomidae family and in Porto da Carne $72 \%$ of individuals belong to the Simullidae family. The ASPT' values are more independent from the number of taxa than the BMWP' values, but depend more on the type of taxa $(\%$ of intolerant taxa). Because the ASPT' values reflect the percentage of intolerant taxa (in general, increasing with the increase in the $\%$ of these taxa), it makes it possible to compare sites with similar BMWP' values, but that differ in the percentage of intolerant taxa (which could reflect differences in ambient conditions). For example, Nascente do Catarredor and Vila Nova de Ceira have the same BMWP' value (36) and the same number of intolerant taxa (3), but the $1^{\text {st }}$ one has 6 BMWP' taxa and the $2^{\text {nd }}$ one has 9 BMWP' taxa. This leads to a higher \% of intolerant taxa in Nascente do Catarredor $(50 \%)$ than in Vila Nova de Ceira (33\%), which explains the

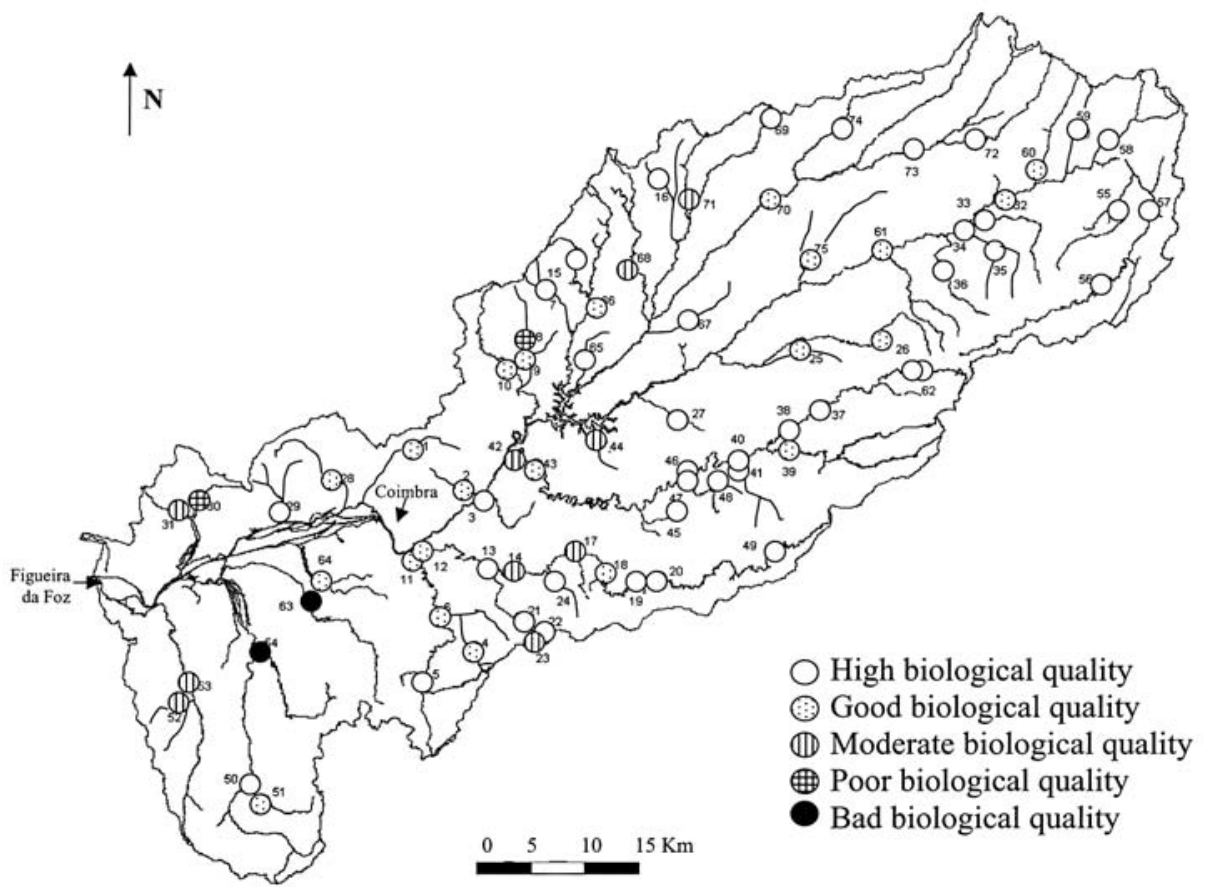

Figure 1: Biological water quality based on BMWP' index in the Mondego river basin. Calidad Biológica del agua en la cuenca hidrográfica del río Mondego, de acuerdo con el índice BMWP'. 
different ASPT' values (6 in the $1^{\text {st }}$ one and 4 in the $2^{\text {nd }}$ one), and is in agreement with the chemical water characteristics. Another example, is the case of Minhocal, Vila Franca da Serra, and Ponte do Espinhal, all with the same BMWP' value (119) and the same number of intolerant taxa (8), but differing in the total number of BMWP' taxa (21, 20 and 19, respectively), which leads to a higher \% of intolerant taxa in Ponte do Espinhal, followed by Vila Franca da Serra and Minhocal, which explains the different ASPT' values $(6.26,5.95$ and 5.67 respectively). This tendency to find higher ASPT' values in sites with the same BMWP' value but that only differ in the $\%$ of intolerant taxa, can be observed in all the cases were the sites have the same BMWP' value (see table 2).

Polluted sites were located mainly in the Lower Mondego region, at low altitudinal sites $(<100 \mathrm{~m}$ asl; just $29 \%$ of sites in class I), at $>50$ $\mathrm{Km}$ from the source (just $21 \%$ of sites in class I), in river sections with a width superior to $10 \mathrm{~m}$ (just $42 \%$ of sites in class I) and lower amounts of CPOM (<5g AFDM/kick sample; $50 \%$ of sites in class I). Conversely, sites with high quality were located in altitudes superior to $400 \mathrm{~m}$ asl $(87 \%$ of sites in class I), at $<10 \mathrm{Km}$ from the source $(64 \%$ of sites in class I), in river sections with a width inferior to $3 \mathrm{~m}(64 \%$ of sites in class I) and higher amounts of CPOM (>10g AFDM/kick sample; $67 \%$ of sites in class I).

Biological water quality was also low at sites with fine sediment (sand; $0 \%$ of sites in class I), low pool quality (just $29 \%$ of sites in class I), and low habitat heterogeneity $(33 \%$ of sites in class I). The Lower Mondego region is characterized by fine sediment, low pool quality, and low habitat heterogeneity. Globally, $44 \%$ of sites had low habitat heterogeneity and were distributed through the whole area.

In terms of water chemistry (Table 3), polluted sites, according to the BMWP', were the ones that had an alkaline $\mathrm{pH}$ (just $39 \%$ of sites in class I) and alkalinity superior to $20 \mathrm{mg} / \mathrm{L}$ (just

Table 3. Geographic (altitude and distance to the source), structural (mean substrate size and CPOM) and chemical (pH, alkalinity, conductivity, ammonia, nitrate, nitrite, chloride, phosphate and sulfate) parameters for the 75 sites sampled in the Mondego river basin, in summer 2001. *The critical threshold (Decreto-Lei 236/98) for the 6 ions is: $\mathrm{NH}_{4}^{+}: 0.05 \mathrm{mg} / \mathrm{L} ; \mathrm{NO}_{3}{ }^{-*}: 25 \mathrm{mg} / \mathrm{L} ; \mathrm{NO}_{2}{ }^{-:}: 0.01 \mathrm{mg} / \mathrm{L} ; \mathrm{Cl}^{-*}: 25 \mathrm{mg} / \mathrm{L} ; \mathrm{PO}_{4}{ }^{2-}$ : $0.4 \mathrm{mg} / \mathrm{L} ; \mathrm{SO}_{4}^{2-:} 5 \mathrm{mg} / \mathrm{L}$. Parámetros geográficos (altitud y distancia al nacimiento del rí), estructurales (tamaño medio del sustrato y CPOM) y químicos ( $\mathrm{pH}$, alcalinidad, conductividad, amonio, nitratos, nitritos, cloro, fosfatos y sulfatos) para las 75 localidades muestreadas en la cuenca del río Mondego, en verano de 2001. *El límite máximo (Decreto-Lei 236/98) para los 6 iones es: $\mathrm{NH}_{4}^{+}: 0.05 \mathrm{mg} / \mathrm{L} ; \mathrm{NO}_{3}$ : $25 \mathrm{mg} / \mathrm{L} ; \mathrm{NO}_{2}^{-}: 0.01 \mathrm{mg} / \mathrm{L} ; \mathrm{Cl}^{-}: 25 \mathrm{mg} / \mathrm{L} ; \mathrm{PO}_{4}{ }^{2-}: 0.4 \mathrm{mg} / \mathrm{L} ; \mathrm{SO}_{4}{ }^{2-}: 5 \mathrm{mg} / \mathrm{L}$.

\begin{tabular}{|c|c|c|c|c|c|c|c|c|c|c|c|c|c|c|c|}
\hline Number & Site & $\begin{array}{l}\text { Altitude } \\
\text { (m) }\end{array}$ & $\begin{array}{c}\text { Distance } \\
\text { to the } \\
\text { source }(\mathrm{Km})\end{array}$ & $\begin{array}{l}\text { Width } \\
(\mathrm{m})\end{array}$ & $\begin{array}{c}\text { Mean } \\
\text { substrate } \\
\text { size }(\mathrm{mm})\end{array}$ & $\begin{array}{c}\text { CPOM } \\
(>1 \mathrm{~mm}, \mathrm{~g} / \\
\text { kick sample) }\end{array}$ & $\mathrm{pH}$ & $\begin{array}{c}\text { Alkalinity } \\
\left(\mathrm{mg} \mathrm{CaCO}_{3} / \mathrm{L}\right)\end{array}$ & $\begin{array}{l}\text { Conductivity } \\
(\mathrm{mS} / \mathrm{cm})\end{array}$ & $\begin{array}{l}\mathrm{NH}_{4}^{+*} \\
(\mathrm{mg} / \mathrm{l})\end{array}$ & $\begin{array}{l}\mathrm{NO}_{2}^{-*} \\
(\mathrm{mg} / \mathrm{l})\end{array}$ & $\begin{array}{l}\mathrm{NO}_{3}^{-*} \\
(\mathrm{mg} / \mathrm{l})\end{array}$ & $\begin{array}{c}\mathrm{Cl}^{-*} \\
(\mathrm{mg} / \mathrm{l})\end{array}$ & $\begin{array}{l}\mathrm{PO}_{4}{ }^{2-*} \\
(\mathrm{mg} / \mathrm{l})\end{array}$ & $\begin{array}{l}\mathrm{SO}_{4}{ }^{2-*} \\
(\mathrm{mg} / \mathrm{l})\end{array}$ \\
\hline 1 & Botão & 80 & 85.442 & 4.20 & 109.2 & 4.99 & 7.70 & 40 & 190.2 & 6.9 & 0 & 3.59 & 14.88 & 0 & 5.61 \\
\hline 2 & Lorvão & 183 & 4.701 & 3.25 & 93.3 & 5.45 & 6.82 & 21 & 123.2 & 36.6 & 0.05 & 6.02 & 13.53 & 0 & 2.37 \\
\hline 3 & Rebordosa & 82 & 8.819 & 2.00 & 94.8 & 3.44 & 6.60 & 18 & 140.7 & 18.8 & 0 & 6.50 & 16.76 & 0 & 2.58 \\
\hline 4 & Tábuas & 310 & 3.433 & 2.50 & 105.6 & 5.56 & 7.35 & 11 & 52.4 & 0.9 & 0 & 0.82 & 8.96 & 0 & 1.01 \\
\hline 5 & Ponte do Espinhal & 181 & 15.174 & 6.90 & 171.7 & 3.98 & 7.97 & 82 & 498.0 & 0 & 0 & 0.00 & 14.34 & 0 & 30.24 \\
\hline 6 & Miranda do Corvo & 118 & 33.271 & 10.50 & 90.6 & 2.87 & 7.76 & 87 & 407.0 & 1626.4 & 0.01 & 0.96 & 16.62 & 0.19 & 14.25 \\
\hline 7 & Tourigo & 300 & 5.792 & 2.60 & 128.3 & 2.20 & 6.53 & 3 & 42.7 & 33.6 & 0 & 2.05 & 6.40 & 0 & 1.10 \\
\hline 8 & Vila Moinhos & 107 & 12.346 & 3.90 & 134.2 & 6.36 & 7.05 & 23 & 81.9 & 11.8 & 0 & 1.36 & 9.01 & 0 & 1.58 \\
\hline 9 & Vila Gozendo & 111 & 16.865 & 6.00 & 92.8 & 7.25 & 7.02 & 7 & 87.2 & 45.9 & 0 & 1.73 & 9.08 & 0 & 2.61 \\
\hline 10 & Póvoa & 115 & 19.785 & 6.00 & 99.2 & 4.44 & 7.12 & 15 & 87.8 & 12.2 & 0 & 3.01 & 9.75 & 0 & 3.44 \\
\hline 11 & Vendas de Ceira 1 & 115 & 102.970 & 12.10 & 53.9 & 2.94 & 7.57 & 27 & 123.1 & 32.6 & 0 & 3.40 & 10.62 & 0 & 3.18 \\
\hline 12 & Vendas de Ceira 2 & 115 & 63.635 & 6.50 & 28.1 & 1.00 & 8.06 & 99 & 410.0 & 5.4 & 0 & 4.21 & 18.12 & 0 & 18.76 \\
\hline 13 & Foz de Arouce & 84 & 86.560 & 26.80 & 77.2 & 2.96 & 7.90 & 14 & 102.9 & 5.1 & 0 & 4.35 & 8.73 & 0 & 2.87 \\
\hline 14 & Casal de Ermio & 71 & 81.975 & 13.00 & 79.2 & 4.04 & 8.31 & 9 & 90.6 & 10.9 & 0 & 3.75 & 10.20 & 0 & 2.48 \\
\hline 15 & Múceres & 71 & 0.834 & 5.70 & 74.7 & 5.21 & 6.71 & 7 & 60.8 & 0 & 0 & 3.29 & 8.01 & 0.09 & 1.44 \\
\hline 16 & Carqueijal & 166 & 4.244 & 5.00 & 129.2 & 7.14 & 6.27 & 7 & 73.5 & 0 & 0.04 & 7.69 & 11.11 & 0.07 & 1.48 \\
\hline 17 & Vila Nova de Ceira & 138 & 69.472 & 12.60 & 144.2 & 2.00 & 7.23 & 11 & 76.3 & 8.1 & 0 & 4.01 & 7.42 & 0 & 2.49 \\
\hline 18 & Góis & 201 & 63.170 & 6.50 & 164.3 & 6.83 & 7.41 & 15 & 63.6 & 18.2 & 0 & 1.67 & 6.00 & 0 & 1.88 \\
\hline
\end{tabular}


Table 3. (Continuation.)

\begin{tabular}{|c|c|c|c|c|c|c|c|c|c|c|c|c|c|c|c|}
\hline 19 & Cabreira & 290 & 31.407 & 6.50 & 118.1 & 1.50 & 7.32 & 11 & 55.5 & 0 & 0 & 1.77 & 5.75 & 0 & 1.79 \\
\hline 20 & Candosa & 330 & 6.500 & 2.70 & 91.1 & 16.05 & 8.24 & 12 & 43.5 & 0 & 0 & 0.51 & 5.59 & 0 & 0.90 \\
\hline 21 & Lousã & 260 & 5.806 & 3.95 & 96.0 & 5.54 & 7.07 & 8 & 53.3 & 0 & 0.05 & 1.09 & 9.43 & 0 & 1.12 \\
\hline 22 & Candal & 620 & 1.502 & 2.00 & 98.9 & 3.32 & 7.09 & 5 & 31.0 & 0 & 0 & 0.44 & 4.75 & 0 & 0.76 \\
\hline 23 & Nascente do Catarredo & dor 730 & 0.546 & 2.60 & 83.3 & 4.69 & 6.82 & 6 & 34.9 & 0 & 0 & 1.01 & 5.45 & 0 & 0.69 \\
\hline 24 & Golpilhares & 219 & 0.809 & 2.10 & 91.1 & 1.16 & 7.76 & 17 & 70.2 & 0 & 0 & 0.58 & 8.96 & 0 & 1.48 \\
\hline 25 & Santa Eulália & 392 & 7.627 & 1.85 & 94.4 & 6.71 & 7.07 & 24 & 134.7 & 724.2 & 0.09 & 4.03 & 15.75 & 0 & 0.247 \\
\hline 26 & Arrifana & 437 & 5.179 & 1.80 & 105.6 & 2.68 & 6.89 & 14 & 115.0 & 33.0 & 0 & 7.67 & 10.86 & 0 & 4.71 \\
\hline 27 & S.João da Boavista & 309 & 3.268 & 1.55 & 76.7 & 1.70 & 7.27 & 12 & 98.2 & 0 & 0 & 4.19 & 16.20 & 0 & 2.08 \\
\hline 28 & Ançã & 30 & 16.902 & 4.10 & 16.0 & 10.22 & 7.79 & 164 & 813.0 & 16.9 & 0 & 12.96 & 19.94 & 0 & 4.47 \\
\hline 29 & Tentúgal & 36 & 6.415 & 2.30 & 18.9 & 2.83 & 8.04 & 141 & 559.0 & 0 & 0 & 13.69 & 22.46 & 0 & 5.26 \\
\hline 30 & Liceia & 22 & 7.380 & 2.25 & sand & 1.46 & 7.92 & 43 & 421.0 & 38.3 & 0 & 4.82 & 28.02 & 0 & 6.24 \\
\hline 31 & Ferreira-a-Nova & 27 & 6.601 & 3.95 & 25.6 & 3.74 & 7.25 & 31 & 223.0 & 16.8 & 0 & 6.90 & 25.76 & 0 & 9.17 \\
\hline 32 & Fornos de Algodres & 345 & 78.993 & 5.70 & 138.9 & 2.37 & 8.03 & 21 & 83.0 & 0 & 0 & 0.09 & 7.85 & 0 & 1.38 \\
\hline 33 & Vila Franca de Serra & 350 & 19.090 & 3.67 & 35.0 & 9.44 & 6.84 & 14 & 86.4 & 229.4 & 0.01 & 3.90 & 9.20 & 0.20 & 1.91 \\
\hline 34 & Ribamondego & 337 & 16.763 & 6.40 & 115.3 & 10.15 & 7.01 & 16 & 77.9 & 15.1 & 0 & 2.66 & 9.55 & 0.54 & 1.83 \\
\hline 35 & Vila Cortêz da Serra & 446 & 4.018 & 3.20 & 100.0 & 6.35 & 6.89 & 11 & 77.2 & 0 & 0 & 2.50 & 9.98 & 0 & 1.66 \\
\hline 36 & Nespereira & 488 & 10.188 & 2.60 & 9.6 & 5.61 & 7.21 & 31 & 161.8 & 6.6 & 0.05 & 18.60 & 20.20 & 0.67 & 4.22 \\
\hline 37 & Sandomil & 318 & 25.873 & 27.00 & 136.9 & 3.19 & 7.31 & 9 & 24.1 & 7.2 & 0 & 0.99 & 3.38 & 0 & 0.40 \\
\hline 38 & Caldas de S.Paulo & 287 & 32.741 & 16.00 & 165 & 4.51 & 7.15 & 5 & 31.9 & 4.4 & 0 & 1.55 & 4.31 & 0 & 0.65 \\
\hline 39 & Alvoco das Várzeas & 279 & 30.409 & 8.00 & 144.2 & 2.78 & 7.22 & 13 & 47.0 & 14.7 & 0 & 2.20 & 5.31 & 0 & 0.99 \\
\hline 40 & Avô 1 & 237 & 42.097 & 6.37 & 167.2 & 1.53 & 7.86 & 9 & 45.1 & 13.4 & 0 & 2.15 & 7.19 & 0 & 0.85 \\
\hline 41 & Avô 2 & 237 & 11.374 & 7.90 & 133.3 & 3.79 & 7.62 & 13 & 63.2 & 7.4 & 0 & 2.64 & 6.39 & 0 & 1.52 \\
\hline 42 & Foz do Alva & 232 & 115.447 & 8.40 & 81.9 & 2.08 & 7.41 & 10 & 50.1 & 21.7 & 0 & 0.93 & 4.28 & 0 & 0.82 \\
\hline 43 & Vimeiro & 97 & 108.625 & 30.00 & 135.6 & 2.18 & 7.32 & 10 & 49.0 & 11.9 & 0 & 1.46 & 5.44 & 0 & 1.04 \\
\hline 44 & S. Paio do Mondego & 129 & 5.936 & 3.20 & 118.4 & 5.17 & 7.07 & 12 & 88.0 & 0 & 0 & 0 & 15.30 & 0 & 1.82 \\
\hline 45 & Folques & 180 & 7.239 & 3.60 & 126.5 & 1.41 & 7.47 & 21 & 96.8 & 21.6 & 0 & 0.67 & 9.51 & 0 & 3.42 \\
\hline 46 & Côja 1 & 178 & 56.291 & 29.00 & 95.6 & 2.78 & 7.33 & 9 & 49.2 & 0 & 0 & 2.75 & 6.01 & 0 & 1.10 \\
\hline 47 & Côja 2 & 191 & 15.896 & 3.85 & 106.7 & 3.31 & 6.97 & 13 & 77.6 & 0 & 0 & 2.56 & 8.59 & 0 & 2.12 \\
\hline 48 & Vinhó & 306 & 4.282 & 1.75 & 38.3 & 1.57 & 7.05 & 15 & 75.5 & 0 & 0 & 1.05 & 9.76 & 0 & 2.00 \\
\hline 49 & Porto da Balsa & 634 & 5.573 & 2.50 & 83.3 & 0.73 & 7.61 & 5 & 38.2 & 0 & 0 & 0.64 & 5.81 & 0 & 0.83 \\
\hline 50 & Pombal & 68 & 21.592 & 8.60 & 81.4 & 2.49 & 7.98 & 94 & 405.0 & 42.9 & 0.13 & 3.83 & 23.49 & 0 & 4.38 \\
\hline 51 & Ponte de Assamaça & 97 & 11.708 & 3.00 & 101.7 & 3.50 & 7.63 & 170 & 542.0 & 49.5 & 0 & 0.22 & 13.58 & 0 & 2.59 \\
\hline 52 & Louriçal & 17 & 6.562 & 3.00 & 47.6 & 1.01 & 7.87 & 56 & 362.0 & 15.7 & 0.06 & 20.56 & 40.80 & 0.41 & 10.48 \\
\hline 53 & Casal da Rola & 19 & 23.900 & 5.70 & sand & 1.20 & 7.5 & 61 & 306.0 & 29.2 & 0.14 & 11.72 & 43.60 & 0 & 4.64 \\
\hline 54 & Soure & 27 & 24.391 & 14.00 & sand & 0.07 & 7.88 & 126 & 598.0 & 36.0 & 0.08 & 9.77 & 39.40 & 0 & 5.80 \\
\hline 55 & Vale dos Azares & 473 & 14.718 & 2.80 & 65.0 & 7.37 & 6.57 & 15 & 55.5 & 0 & 0 & 0.55 & 6.46 & 0 & 1.37 \\
\hline 56 & Trinta & 800 & 33.609 & 5.00 & 150.6 & 1.10 & 7.10 & 7 & 25.7 & 48.2 & 0 & 0.35 & 2.94 & 0 & 0.36 \\
\hline 57 & Porto da Carne & 455 & 51.188 & 14.90 & 121.7 & 4.51 & 6.76 & 8 & 51.4 & 23.5 & 0 & 1.07 & 3.97 & 0 & 1.17 \\
\hline 58 & Minhocal & 460 & 15.044 & 3.50 & 58.9 & 5.35 & 6.61 & 26 & 101.1 & 0 & 0 & 0.71 & 63.71 & 0.37 & 19.00 \\
\hline 59 & Cardal & 437 & 7.503 & 3.00 & 100.0 & 3.12 & 6.87 & 13 & 58.8 & 51.3 & 0 & 2.62 & 5.80 & 0 & 1.26 \\
\hline 60 & Muxagata & 380 & 14.738 & 6.50 & 97.8 & 2.21 & 6.45 & 20 & 83.1 & 0 & 0 & 0.13 & 8.86 & 0 & 1.12 \\
\hline 61 & Póvoa da Rainha & 260 & 99.152 & 10.20 & 173.3 & 2.12 & 7.41 & 22 & 87.2 & 0 & 0 & 0 & 8.22 & 0 & 1.14 \\
\hline 62 & Sabugueiro & 1040 & 5.277 & 2.70 & 111.1 & 1.57 & 6.90 & 5 & 19.2 & 43.5 & 0 & 0.59 & 2.62 & 0 & 0.26 \\
\hline 63 & Campizes & 30 & 5.924 & 4.70 & sand & 2.19 & 7.50 & 119 & 682.0 & 0 & 0.02 & 5.06 & 30.28 & 0 & 12.45 \\
\hline 64 & Anobra & 25 & 13.318 & 1.80 & 53.3 & 11.17 & 8.05 & 16 & 762.0 & 36.8 & 0.12 & 15.54 & 21.94 & 0 & 42.71 \\
\hline 65 & Vila da Barba & 229 & 6.748 & 2.85 & 16.1 & 7.91 & 5.96 & 15 & 185.7 & 0 & 0 & 19.35 & 21.37 & 0 & 4.14 \\
\hline 66 & Várzea & 136 & 23.969 & 2.75 & 122.2 & 3.54 & 6.53 & 12 & 111.2 & 15.7 & 0 & 8.22 & 15.34 & 0 & 2.58 \\
\hline 67 & Travanca de S.Tomé & 247 & 11.000 & 2.20 & 128.9 & 9.22 & 6.01 & 17 & 156.0 & 18.7 & 0.03 & 0 & 17.05 & 0 & 5.69 \\
\hline 68 & Tondela & 250 & 22.072 & 7.30 & 51.9 & 6.32 & 6.49 & 9 & 81.3 & 36.6 & 0 & 5.32 & 10.58 & 0 & 1.31 \\
\hline 69 & Casal de Mundão & 547 & 2.445 & 1.90 & 63.3 & 9.76 & 6.61 & 21 & 104.4 & 3.0 & 0 & 1.64 & 6.02 & 0 & 0.87 \\
\hline 70 & Alcafache & 238 & 50.579 & 7.00 & 221.4 & 1.38 & 7.04 & 19 & 114.5 & 10.1 & 0 & 0.58 & 6.59 & 0 & 1.50 \\
\hline 71 & Fail & 325 & 19.548 & 3.00 & 60.6 & 4.26 & 7.27 & 68 & 593.0 & 5631.3 & 0.21 & 10.36 & 81.00 & 5.31 & 10.78 \\
\hline 72 & Antas & 538 & 18.337 & 4.50 & 112.8 & 0.04 & 6.89 & 15 & 66.7 & 0.2 & 0 & 0.76 & 9.96 & 0 & 0.72 \\
\hline 73 & Penalva do Castelo & 388 & 27.474 & 2.00 & 105.5 & 4.32 & 6.76 & 8 & 78.6 & 4.4 & 0 & 0 & 10.05 & 0 & 0.46 \\
\hline 74 & S.Miguel da Vila Boa & 405 & 15.114 & 3.00 & 74.4 & 110.40 & 7.07 & 22 & 136.6 & 0 & 0 & 5.28 & 15.19 & 0 & 2.02 \\
\hline 75 & Senhorim & 369 & 19.533 & 3.30 & 126.4 & 3.51 & 6.19 & 25 & 136.6 & 19.4 & 0 & 0.50 & 21.11 & 0 & 11.24 \\
\hline
\end{tabular}




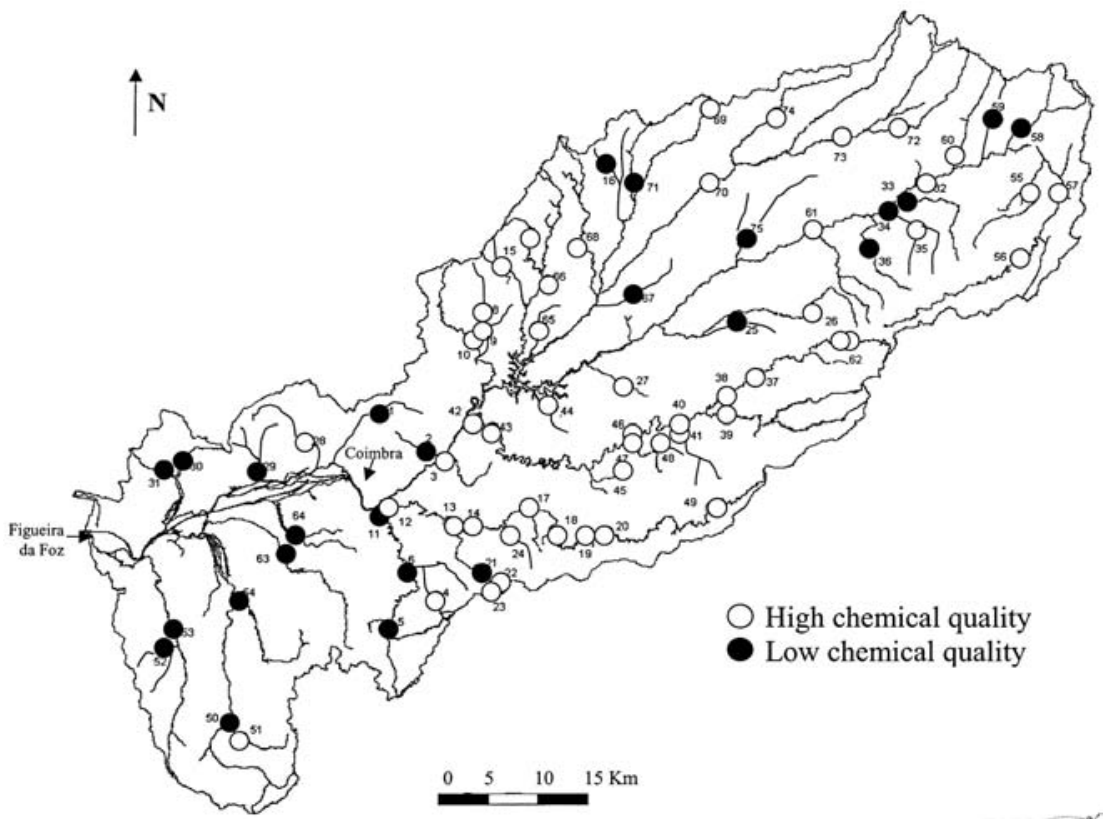

Figure 2. Chemical water quality (at least one ion to excess; see text) index in the Mondego river basin. Calidad quimica del agua en la cuenca hidrográfica del río Mondego (al menos 1 ion en exceso; ver texto).

$25 \%$ of sites in class I). With respect to ions, ammonia was in excess $(>0.05 \mathrm{mg} / \mathrm{L})$ in 5 sites $(7 \%)$; nitrite was in excess $(>0.01 \mathrm{mg} / \mathrm{L})$ in 15 sites $(20 \%)$; chloride was in excess $(>25 \mathrm{mg} / \mathrm{L})$ in 8 sites $(11 \%)$; phosphate was in excess $(>0.4$ $\mathrm{mg} / \mathrm{L})$ in 4 sites $(5 \%)$ and sulfate was in excess $(>5 \mathrm{mg} / \mathrm{L})$ in 15 sites $(20 \%)$. Globally, there were 25 sites $(33 \%)$ with at least one ion in excess, $9(36 \%)$ of them in the Lower Mondego region (Fig. 2). Thus, 33\% of sites had bad chemical water quality. In the Lower Mondego region, bad chemical water quality was reflected in conductivity that in this region exceeded $400 \mu \mathrm{S} / \mathrm{cm}$ in the majority of sites. Low values of BMWP' can then be explained by low chemical quality and/or habitat heterogeneity (Table 4).

The low BMWP' scores in the Lower Mondego region (Table 2 and Fig. 1) can be explained by the reduced number of individuals belonging to sensitive taxa, which can reflect the lower chemical water quality and the lower habitat heterogeneity in this area. For example, Soure, Campizes and Liceia presented none (Campizes) or only a few (max. of 5, Soure and Liceia) individuals from the orders Trichoptera, Ephemeroptera and Plecoptera. Casal da Rola (BMWP' = 41) presented no Plecoptera, and the Ephemeroptera (all Baetidae) and Trichoptera (all Hydropsychidae) accounted for only $0.6 \%$ and $0.4 \%$, respectively, of the total number of individuals; dipterans represented $90 \%$ of the total number of individuals in this site. Louriçal (BMWP'=45) presented only $6.8 \%$ of Ephemeroptera individuals (all Baetidae) and 8\% of Trichoptera (all Hydropsychidae) individuals. Ferreira-a-Nova $(B M W P '=53)$ presented $34 \%$ of Ephemeroptera (most of them Baetidae) and Trichoptera (most of them Hydropsychidae) individuals. For these sites it seems that the BMWP' index reflected the poor chemical water quality. However, for Casal Ermio, Vila Nova de Ceira, Foz do Alva, S.Paio do Mondego and Nascente do Catarredor (located in the medium part of the basin), the BMWP' values (between 36 and 50), can only be explained by the low quality of structural parameters; reduced mean size of the substrate and/or poor pool quality, which results in a low habitat heterogeneity, since all the chemical parameters were 
Table 4. Relationship between biological water quality classes and combinations of chemical quality and habitat complexity for sites in the Mondego river basin. Relación entre clases de calidad biológica y combinaciones de calidad química y complejidad de hábitat para las localidades de la cuenca del río Mondego.

\begin{tabular}{cccccc}
\hline Biological quality & $\begin{array}{c}\text { Bad chemical quality } \\
\text { +Low habitat complexity }\end{array}$ & Bad chemical quality & Low habitat complexity & $\begin{array}{c}\text { Good chemical quality } \\
\text { +High habitat complexity }\end{array}$ \\
\hline Classes & $\mathbf{N}^{\mathbf{0}}$ of sites & \% of sites & \% of sites & \% of sites & \% of sites \\
\hline I & 39 & 8 & 18 & 18 & 56 \\
II & 22 & 35 & 0 & 22 & 43 \\
III & 10 & 30 & 10 & 50 & 0 \\
IV & 2 & 50 & 0 & 0 & 0 \\
V & 2 & 100 & 0 & 50 & 0 \\
\hline
\end{tabular}

within acceptable intervals. For Tondela, and extra explanation can be the high nitrate concentration in the water. In Ribamondego the highest BMWP' value (206) was achieved due to the presence of a high number of individuals belonging to 34 taxa. However, upstream of this site there was a domestic effluent, but because this was not reflected in an increase of the ions concentrations in the water, beyond threshold values the aquatic community was not negatively affected.

\section{DISCUSSION}

In general, in the Mondego basin area, the lower section had lower water quality than the upper section. This information was generally consistent with the chemical water quality. However, some inconsistencies were observed, mainly in some upper sections where low biological water quality was obtained for zones with high chemical quality. The lower sections were also the ones naturally having fine substrate particle sizes, high ion concentrations (nitrite, chloride, and sulfate), and high conductivity, and proportionally high amounts of fine particulate organic matter.

The lower value of BMWP' in the lower sections of the Mondego basin has two not mutually excluding explanations. Firstly, the lower sections are the ones receiving more pollutants due to (a) transport from upstream, (b) high population density through domestic sewage, (c) high industrial activities through industrial sewage and (d) high agricultural activities through the use of large amounts of fertilizers and pesticides. Therefore, the BMWP' seems to be responding, as desired, to environmental degradation.

Secondly, BMWP' values could be biased by the ecology of indicator taxa. In general, low order rivers had higher amounts of CPOM whereas high order rivers had high amounts of FPOM. Shredders, invertebrates feeding on CPOM, have generally "high scores" in the BMWP' table (indicators of high water quality), whereas invertebrates feeding on FPOM (filterers and gatherers) have lower scores (Armitage et al., 1983; Alba-Tercedor \& Sánchez-Ortega, 1988; Alba-Tercedor, 1996; Tachet et al., 2000). Low order rivers are also characterized by intolerant taxa to low oxygen and flow conditions, these taxa being recorded as intolerant in the BMWP' family list. Conversely, taxa inhabiting lowland streams and rivers are naturally more tolerant to low oxygen conditions since in the depositional areas the decomposition of organic matter under low flow conditions could cause natural decreases in dissolved oxygen. Another feature that can influence the distribution of shredders is the size of the substrate, because shredders prefer stony substrate rather than sandy ones; for example, the Trichoptera families that shred (Sericostomatidae, Leptoceridae, Lepidostomatidae, Phryganidae and Calamoceratidae) were found mostly in the middle and upper part of the basin, while in the lower part of the basin we only found Sericostomatidae 
(Anobra), Lepidostomatidae (Pombal), Leptoceridae (Pombal and Ponte de Assamaça) and Calamoceratidae (Tentúgal and Louriçal). Therefore, the BMWP' index seems to be influenced by habitat heterogeneity. Stream with sandy substrates are simpler and provide less niches capable of being colonized by invertebrates (Graça et al., 1989). This dependence may be desirable if decreases in habitat heterogeneity are related to human activities, but undesirable if habitats with low complexity are natural. Low habitat complexity explained low BMWP' scores in a greater number of sites than bad chemical water quality. Therefore, the BMWP' index was sensitive to structural parameters (low habitat heterogeneity), classifying clean sites as polluted.

Besides the problems of possible mismatching sites, biotic indices are useful tools since they integrate the biological information when evaluating water quality.

\section{ACKNOWLEDGMENTS}

This research was supported by the regional Environment Authorities "Direcção Regional de Ambiente e Ordenamento do Território DRAOT", project no 600034 930. We are grateful to Dr. Elsa Rodrigues for doing the water chemical analysis, Sónia Costa and Gisela Gonçalves for their assistance in the laboratory and Victor Ramos for his help in the field. We also appreciated the helpful comments of two anonymous reviewers.

\section{BIBLIOGRAPHY}

ALBA-TERCEDOR, J. \& S. SÁNCHEZ-ORTEGA. 1988. Un método rápido y simple para evaluar la calidad biológica de las aguas corrientes basado en el de Hellawell (1978). Limnetica, 4: 51-56.

ALBA-TERCEDOR, J. 1996. Macroinvertebrados acuaticos y calidad de las aguas de los rios. IV SIAGA, Almería, II: 203-213.

A.P.H.A. 1995. Standard methods for the examination of water and wastewater, 19th ed. American Public Health Association, Washington, D.C.
ARMITAGE, P. D., D. MOSS, J. F. WRIGHT \& M. T. FURSE. 1983. The performance of a new biological water quality score system based on macroinvertebrates over a wide range of unpolluted running-water sites. Water Res., 17: 333-347.

BARBOUR, M. T., J. MORENO, B. D. SNYDER \& J. B. STRBLING. 1999. Rapid bioassessment protocols for use in wadeable streams and rivers. Periphyton, benthic, macroinvertebrates, and fish. USEPA. Washington, DC. United States.

BLIJSWIJK, W. V., C. N. COIMBRA, M. A. S. GRAÇA. 2005. The performance of two biotic indices based on macroinvertebrates on an Iberian stream (Central Portugal) receiving a paper mill effluent. Limnetica, 23(3-4): 307-314.

CALLISTO, M., P. MORENO \& F. A. R. BARBOSA. 2001. Habitat diversity and benthic functional trophic groups at Serra do Cipó, southeast Brazil. Rev. Brasil. Biol., 61: 259-266.

DGF. 2003. http://www.dgf.min-agricultura.pt/v4/ dgf/pub.php?ndx=126)

GRAÇA, M. A. S., D. M. FONSECA \& S. T. CASTRO. 1989. The distribution of macroinvertebrate communities in two Portuguese rivers. Freshwat. Biol., 22: 297-308.

INAG. 2003. http://snirh.inag.pt/cgi-bin/anual/ qual_agua/pag_usos.tcl?7\&usos).

INAG. 2003. http://snirh.inag.pt/cgi-bin/anual/ qual_agua/pag_fp.tcl?7\&fp)

MARQUES, J. C., M. A. S. GRAÇA \& M. A. PARDAL. 2002. Introducing the Mondego river basin. In: Aquatic ecology of the Mondego river basin. Global importance of local experience. J. C. Marques,

M. A. S. Graça \& M. A. Pardal (eds.): 7-12. Universidade de Coimbra, Coimbra, Portugal.

METCALFE, J. 1989. Biological water quality assessment of running waters based on macroinvertebrate communities: history and present status in Europe. Environmental Pollution, 60:101-139.

OLIVEIRA, R. L., M. A. S. GRAÇA \& C. N. COIMBRA. 2001. Cartografia da qualidade da água na bacia do Mondego, com base em macroinvertebrados. Actas VII conferência Nacional sobre a Qualidade do Ambiente, Aveiro, Portugal: 580-583.

ROCHA, I \& D. F. VIEIRA. 1998. Água. Legislação. Contencioso contra- ordenacional. Jurisprudência. Porto Editora. Portugal.

TACHET, H., P. RICHOUX, M. BOURNAUD et P. USSEGLIO-POLATERA. 2000. Invertébrés d'eau douce. Systématique, biologie, écologie. CNRS Editions, Paris. 